\title{
酸化鉄触媒によるグリセリンからの有用化学物質直接合成
}

\section{Production of Useful Chemicals from Glycerol over Iron-oxide Catalyst}

\section{多湖 輝興}

東京工業大学物質理工学院

T 151-8552

東京都目黒区大岡山 2-12-1（S1-5）

Teruoki TAGO

School of Materials and Chemical

Technology, Tokyo Institute of

Technology

2-12-1, Ookayama, Meguro-ku, Tokyo 152-8552, Japan

中坂 佑太

北海道大学大学院工学研究院

厂 060-8628

札幌市北区北 13 条西 8 丁目

Yuta NAKASAKA

Faculty of Engineering, Hokkaido University

North 13, West 8, Kita-ku, Sapporo, Hokkaido 060-8628, Japan

\section{増田 隆夫}

北海道大学大学院工学研究院

T 060-8628

札幌市北区北 13 条西 8 丁目

Takao MASUDA

Faculty of Engineering, Hokkaido University

North 13, West 8, Kita-ku, Sapporo, Hokkaido 060-8628, Japan
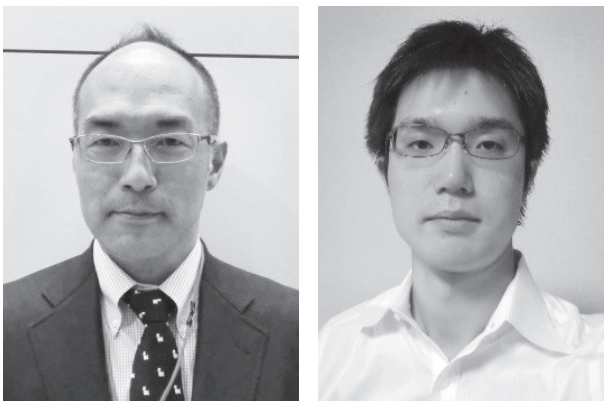

吉川 环也

北海道大学大学院工学研究院

T 060-8628

札幌市北区北 13 条西 8 丁目

Takuya YOSHIKAWA

Faculty of Engineering, Hokkaido

University

North 13, West 8, Kita-ku, Sapporo,

Hokkaido 060-8628, Japan
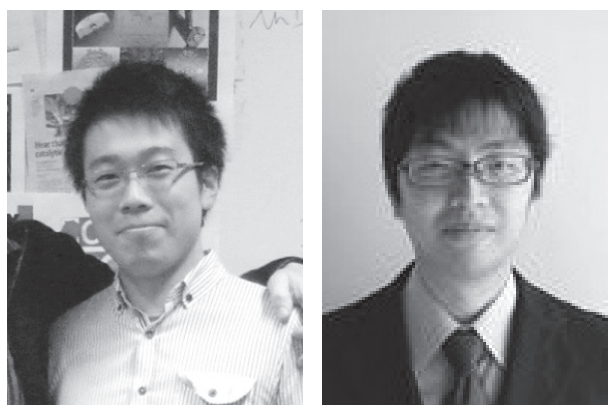

藤墳 大裕

東京工業大学物質理工学院

广 151-8552

東京都目黒区大岡山 2-12-1（S1-5）

Hiroyasu FUJITSUKA

School of Materials and Chemical

Technology, Tokyo Institute of

Technology

2-12-1, Ookayama, Meguro-ku, Tokyo 152-8552, Japan

論文要旨:バイオディーゼル燃料を製造する際に副生するグリセリンの有効利用法の開発が望まれている。 酸化鉄を主成分とする触媒を用いたグリセリン転換反応では，アリルアルコールとプロピレンが生成する反 応経路 I とアセトール，カルボン酸とケトン類が主に生成する反応経路 II に従って反応が進行する。BDF 製造時に副生する粗製グリセリンに対し，同触媒反応系を適用すると，プロピレンとケトン類を生成させる ことに成功した。さらに，酸化鉄へのカリウムの担持，および反応系へのギ酸の併給は，グリセリンからの アリルアルコール収率向上（約 40\%）に有効であることを見出した。触媒の結晶性と酸特性を評価したと ころ、反応系中のギ酸由来水素により触媒の結晶性はへマタイト構造 $\left(\alpha-\mathrm{Fe}_{2} \mathrm{O}_{3}\right)$ からマグネタイト構造 $\left(\mathrm{Fe}_{3} \mathrm{O}_{4}\right)$ へ還元されること、および触媒上にブレンステッド酸点が新たに形成されることが明らかとなった。 したがって、マグネタイト構造の触媒上に新たに形成した酸点により、グリセリンからのアリルアルコール 生成が促進したと考えられる。 
Abstract: Development of effective usage for glycerol produced as a by-product during biodiesel production is desired. In glycerol conversion using iron-oxide based catalyst, useful chemicals such as allyl alcohol, propylene (Pathway I) and acetol, carboxylic acid and ketones (Pathway II) were obtained. Propylene and ketones were successfully obtained during the glycerol conversion in accordance with these reaction pathways. Moreover, we found that the dehydration reaction in Pathway II was suppressed by loading potassium on iron oxide catalyst and that the addition of formic acid into the reaction system enhanced allyl alcohol production. In addition, it was revealed that the potassium loading decreased the Lewis acidity and the Brønsted acid sites were newly formed during the reaction, where the hematite structure $\left(\alpha-\mathrm{Fe}_{2} \mathrm{O}_{3}\right)$ was changed into the magnetite structure $\left(\mathrm{Fe}_{3} \mathrm{O}_{4}\right)$. Therefore, it was concluded that the production of allyl alcohol from glycerol was promoted by the Brønsted acid sites newly formed on the iron oxide catalyst during the structure change to magnetite.

Key words: glycerol, magnetite, formic acid, allyl alcohol

\section{1 はじめに}

化石資源である原油と動植物由来の油脂は，エネル ギー源, 化成品基礎原料, 食品・医薬品等として我々の 日常生活に不可欠である。植物由来の代表的な油種は, 大豆油, パーム油, 菜種油, ひまわり油, ヤシ油などが 挙げられ，第二次世界大戦前後では主に工業用として， 1980 年以降では食用（約 80\%）として利用されてきた。 特に, 油脂の工業利用では, 脂肪酸とグリセリンへ加水 分解され, 界面活性剤 (洗剂, 化粧品等) として利用さ れてきた。一方, 近年では, 地球温暖化防止国際会議で 提唱されたカーボンニュートラルと二酸化炭素排出量削 減に関する考えに基づき, 食用や界面活性剤などの従来 の用途に加えて，バイオディーゼル燃料 (BDF) として の利用が検討されている。ただし， BDF 製造を展開する 各国の意困は，環境対策に加えて国内の農業政策として の BDF の導入, パーム油の価格維持対策としての BDF 製造など，様々である。ディーゼル車が普及し，BDFの 生産が最も盛んな EUにおいては, BDF の軽油への混合 割合は最近 10 年で約 $2 \%$ から $6 \%$ 程度まで増加してい る。日本では, 耕作地が限られるため菜種油や大豆油で の $\mathrm{BDF}$ 製造は不適であり, 事業所から出る廃植物油を $\mathrm{BDF}$ へ転換するプロセス開発が進められてきた 11

$\mathrm{BDF}$ として最も一般的に利用されている脂肪酸メチ ルエステル（FAME）は，上記で述べたように主に植 物油から製造され，コストや技術面の問題から $\mathrm{KOH}$ な どの均一系触媒が製造工程に用いられている。そのため, 原料油脂とメタノールから合成される FAME 以外に, アルカリ金属や遊離脂肪酸など多量の不純物が含まれる 粗製グリセリンが副生する。 BDF 製造時に副生するグ リセリン（粗製グリセリン）の実廃液について成分分析 を行った結果を Fig. 1 に示す ${ }^{2)}$ 。元素分析計により粗製 グリセリン中の可溶化炭素量を測定し, 含有する有機物 をガスクロマトグラフィーによって定性・定量した。無

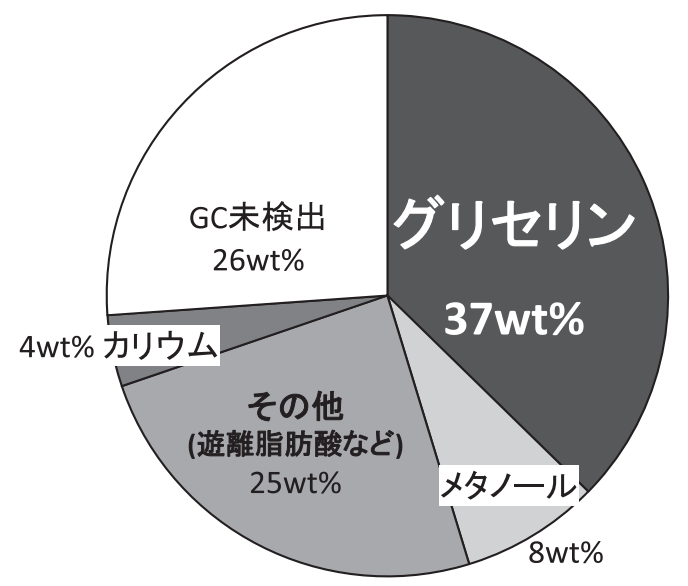

Fig. 1 Components of crude glycerol.

機物については蛍光 X 線分析計 $(\mathrm{XRF})$ を用いて定性・ 定量を行った。元素分析の結果, 粗製グリセリン中の約 $37 \mathrm{wt} \%$ がグリセリンであり，それ以外の有機物として， メ夕ノール, 遊離脂肪酸, その他の炭化水素系残椬など が不純物として含まれる。遊離脂肪酸および炭素残椬な どは，図中のその他および不明成分に該当する。グリセ リンは水と任意の割合で混合することに加え, 未反応の メ夕ノールや触媒に由来するカリウムなどのアルカリ金 属が含まれているため, 精製が困難となっている。また, 近年のバイオディーゼル燃料の普及により，グリセリン が供給過剰となっており, 市場価格の下落が続いてい る。BDFの普及のためには, 副生するグリセリンの用 途開発が不可欠である ${ }^{3,4)}$

一方で, BDF 用途開発のためのグリセリン利用に加 えて，グリセリン自身がバイオマスリファイナリーの汎 用 C3 プラットフォーム化合物であり, グリセリンの利 用方法の 1 つとして, 石油化学製品への転換が提案され ている。グリセリンは 3 つの炭素全てがヒドロキシ基を 有する多官能性物質であるため非常に反応性に富み, Fig. 2 に示すような有用化学物質への転換が多数報告さ れている。具体的には，グリセリンの水素化分解による 


\section{担持貴金属触媒による水素化反応}

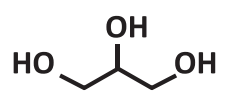

Glycerol

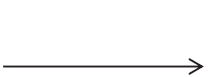

2

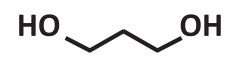

1,3-PDO

\section{固体酸触媒による脱水反応}

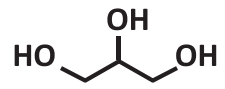

Glycerol

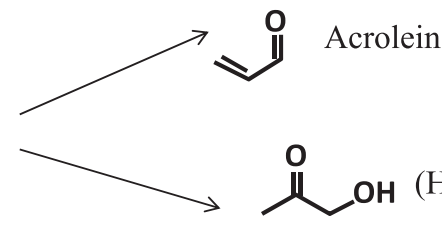
Hydroxyacetone)

Fig. 2 Conversion of glycerol into useful chemcials.

1,2-, 1,3- プロパンジオール（1,2-, 1,3-PDO）の生成は, $\mathrm{Ru}, \mathrm{Rh}, \mathrm{Pt}$ などの貴金属担持触媒上で進行する ${ }^{5-9)}$ 。 一方，グリセリンの気相脱水反応によるアクロレインや ヒドロキシアセトンの生成は，それぞれへテロポリ酸， ゼオライト，あるいは銅系触媒で進行することが報告さ

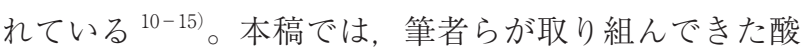
化鉄系触媒によるグリセリンからの基礎化学物質（ケト ン，アリルアルコール，プロピレン）合成，特にアリル アルコール合成について紹介する。酸化鉄系触媒による グリセリンからの基礎化学物質合成では, 並列反応と逐 次反応が組み合わさった複雑な反応経路により生成物が 得られる。グリセリンからのアリルアルコール選択合成 に至るまでの経緯を，BDF 合成時に副生する粗製グリ セリンへの適用例と併せて紹介する。

\section{2 酸化鉄系触媒}

粗製グリセリンなどの廃呆物を基礎化学物質に転換す るためには，グリセリンに活性を示すと共に，アルカリ 金属，ポリグリセリン，遊離脂肪酸などが多量に含まれ ている不純物に対して耐性を有することが必要となる。 これに対し, 筆者らは酸化鉄複合触媒 $\left(\mathrm{ZrO}_{2}-\mathrm{FeOX}\right.$ 触媒, $\mathrm{Al}_{2} \mathrm{O}_{3}-\mathrm{ZrO}_{2}-\mathrm{FeOX}$ 触媒等) を開発し ${ }^{16}$ ), 残油 (常圧残油, オイルシェル等）やバイオマスタール（下水污泥可溶化 液，および家畜粪尿可溶化液）の転換反応を実施した。 同触媒を用いることで超重質油の軽質化 ${ }^{17,}{ }^{18)}$ ，および バイオマス廃棄物の一つであるパームシェルオイルから アセトンやブタノンなどのケトン類とフェノールの生成 することに成功している ${ }^{19-23)}$ 。今回使用した粗製グリ セリンには, Fig. 1 に示したようにグリセリン以外に, 水, アルカリ金属, 遊離脂肪酸, メ夕ノールが含まれる。 上述したように，酸化鉄系触媒はバイオマスタールに含 まれる含酸素高分子や超重質油に対し，耐性と分解活性 を有すると共に, これらの原料に含まれる金属種に対し
ても耐性を有すると考えられる。したがって，粗製グリ セリン中の遊離脂肪酸などの高分子炭化水素を酸化分解 し，触媒への析出を抑制することが期待できる。さらに 同触媒は水共存下で活性を示すため高含水の原料にも使 用できる。以上の理由から，含水グリセリンや粗製グリ セリン溶液に含まれるグリセリン分子内のアルコール性 水酸基に活性を示すと共に触媒活性劣化成分に対し耐性 を持つ触媒として，酸化鉄系触媒を適用した ${ }^{24-26)}$ 。

酸化鉄系触媒は, 各金属の硝酸塩水溶液にアンモニア 水を滴下する共沈法により調製した。また，カリウムの 担持は, 硝酸カリウム水溶液を使用する含浸法により実 施した。グリセリンの転換反応実験は, 上記触媒を充填 した常圧固定層流通式触媒反応器に, シリンジポンプに てグリセリン水溶液を給し, 窒素雲囲気下, 反応温度は $350^{\circ} \mathrm{C}$ で実施した。反応生成物は氷冷トラップとサンプ リングバッグで液体と気体に分離して全量を捕集し, GC-MS と GC により同定・定量した。

\section{3 グリセリンからの基礎化学物質合成}

\section{$3 \cdot 1$ 粗製グリセリンからの基礎化学物質合成}

酸化鉄系触媒による粗製グリセリンからの基礎化学物 質合成を検討した。触媒には，ジルコニアを含む $\mathrm{ZrO}_{2}$ $\mathrm{FeOX}$ 触媒を, 反応器には固定層流通式反応器を使用し た。生成物収率と反応経路を Fig. 3 と Fig. 4 にそれぞれ 示す。Fig. 3 では, 供給したグリセリンの炭素数を基準 として生成液と生成ガス中に含まれる物質の炭素収率を 示した。

無触媒の場合は, 熱分解反応によりヒドロキシアセト ン, カルボン酸, ケトン類がわずかに生成したが, 主成 分は未反応グリセリンであった。一方, 酸化鉄系を使用 した場合, アリルアルコールとプロピレン（後述する反 応経路 I に由来)，ヒドロキシアセトン，カルボン酸， ケトン類, アクロレインを主成分とするアルデヒド類(後 


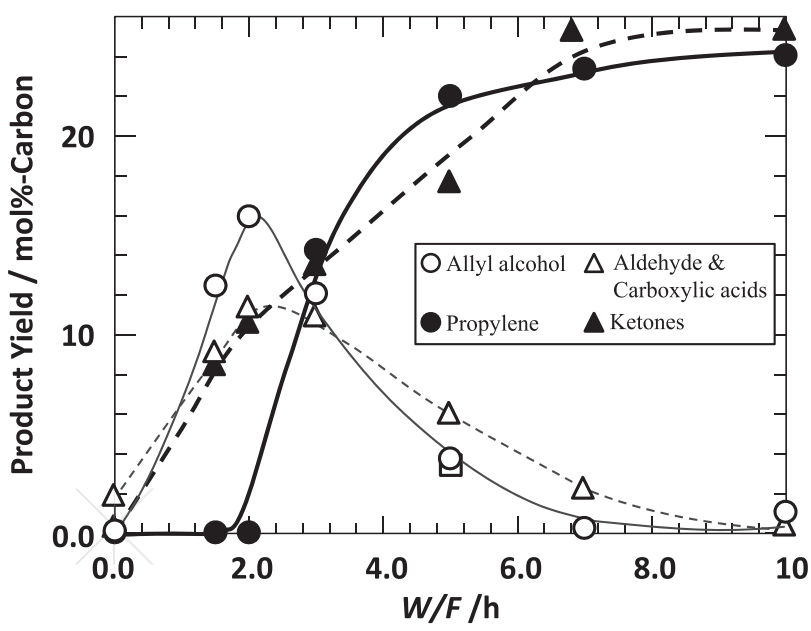

Fig. 3 Effect of the $W / F$ value on the yield of majior products during the conversion of crude glycerol.

述する反応経路 IIに由来）が観察された。このように多 種類の生成物が得られているが，これらの生成物収率は 触媒量と供給グリセリン重量比 $W / F[\mathrm{~s}]$ （触媒重量 $W$ $[\mathrm{kg}]$,供給グリセリン量 $F[\mathrm{~kg} / \mathrm{h}] ）$ に大きく依存する。 重量比 $W / F=1.0 \sim 2.0 \mathrm{~h}$ の条件では，上記の成分が観察 される。一方，W/Fを大きくすると，アリルアルコー ルとカルボン酸の生成量が最大值を示し，その後減少す る。それと同時に, プロピレンとケトン類（アセトン， ブタノンが主成分）の収率が上昇し，W/F>5 h 以上で はほぼ一定となる。反応の進行と生成物の観点から, 酸 化鉄系触媒によるグリセリン転換反応では, 最終生成物 がプロピレンとケトン類に至る，並列・逐次反応が進行 していると考えられる。また, 様々なバイオマスや超重 質油に対し活性を示す酸化鉄系触媒は，粗製グリセリン に含まれる遊離脂肪酸やアルカリ金属に対し耐性を有
し，プロピレンとケトン類の合成が可能であることが示 された ${ }^{25)}$ 。

試薬グリセリン，および Fig. 3 で得られた反応中間体 (グリセリン以外に，ヒドロキシアセトン，酢酸，アセ卜 ン, アクロレイン, アリルアルコールの各水溶液）を原 料に用い, 酸化鉄とその他の金属酸化物（アルミナ, チ タニア, 酸化コバルト, ジルコニア）による反応試験を 実施した。反応原料は $10 \mathrm{wt} \%$ 水溶液とした。想定され る反応経路を Fig. 4 に示す。ジルコニアを触媒に使用し た場合, 一般的に上く知られている酸触媒による脱水反 応（アクロレイン生成, ヒドロキシアセトン生成）が進 行する。1位の炭素に結合した水酸基が脱水する場合は ヒドロキシアセトンが生成し， 2 位の炭素に結合した水 酸基が脱水する場合, アクロレインが生成する。酸化ア ルミニウム, 酸化チタン, 酸化コバルトの各種金属酸化 物を触媒に使用した場合も, ジルコニアと同様に主に脱 水が進行した。アクロレインはそれ以上反応することは ないが, ヒドロキシアセトンはさらに反応してカルボン 酸となり, 同カルボン酸は脱炭酸を伴う 2 量化によりケ トン類へと転換される。一方, 酸化鉄を触媒に使用した 場合, 上記の脱水反応によるヒドロキシアセトンとアク ロレイン生成反応に加えて, アリルアルコール生成反応 が進行する。そして, 生成したアリルアルコールは逐次 的にプロピレンへ転換される。以上より,生成物としては, Fig. 4 に示すように多様な化学物質が得られるが, 反応 経路 I と反応経路IIに従って, 逐次的に反応が進む。反 応経路 I では, グリセリンからアリルアルコールが生成 し, さらにアリルアルコールからプロピレンが得られる。 一方, 反応経路IIでは, グリセリンからヒドロキシアセ トンが生成し，カルボン酸を経由してケトン類に至る。

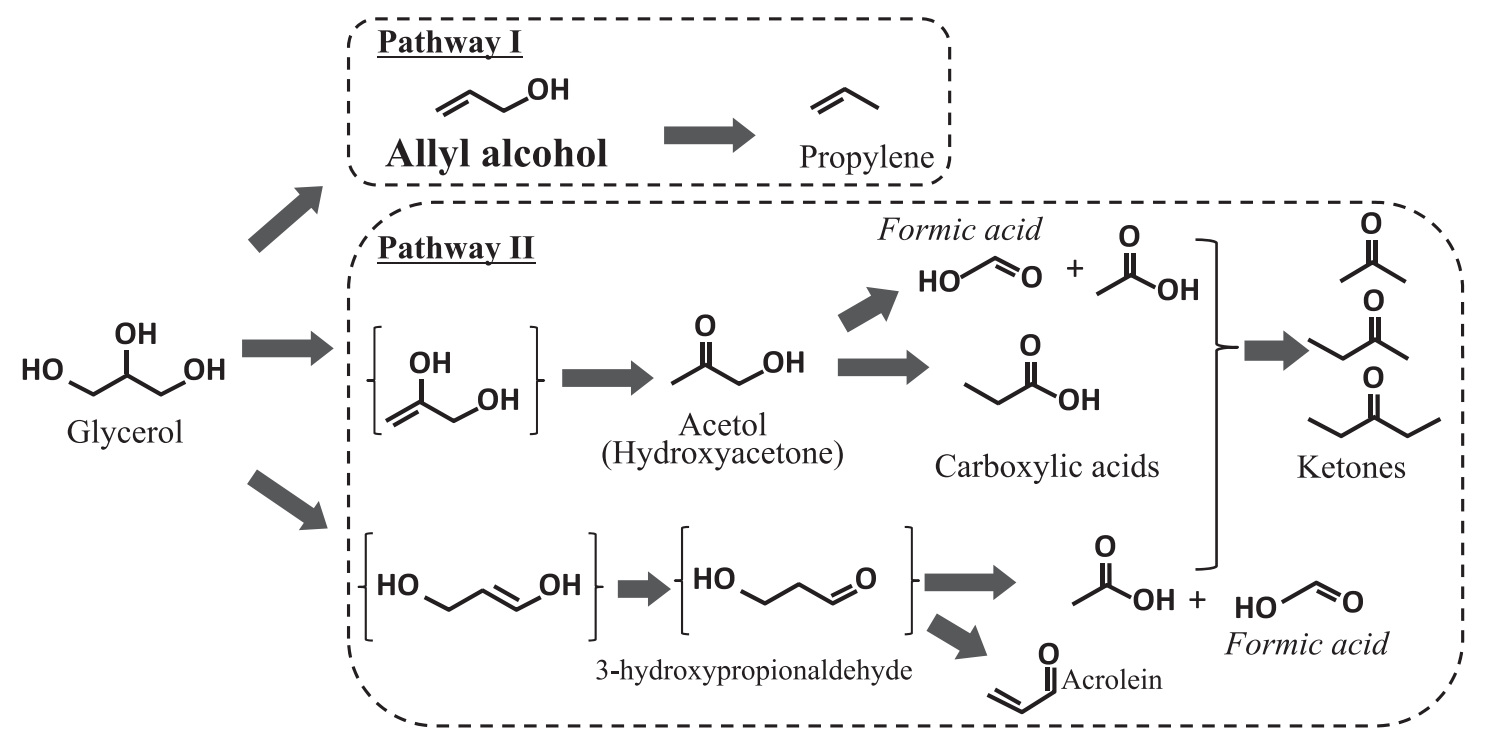

Fig. 4 Expected reaction pathway from glycerol over iron oxide-based catalyst. 
反応経路 I のアリルアルコールとプロピレンが生成する 反応経路は酸化鉄系触媒に特徴的な反応である ${ }^{24,25)}$ 。

\section{$3 \cdot 2$ アリルアルコール選択合成}

粗製グリセリンを原料とした反応では，原料に含まれ るアルカリ金属（K イオン）の一部は反応中に触媒上に 蓄積すると考えられる。そこで，アルカリ金属が酸化鉄 系触媒に及ぼす影響を検討するため，予めカリウムを酸 化鉄触媒に含浸担持し，グリセリンの転換反応を実施し た。 $\mathrm{K}$ を $\mathrm{Fe}$ に対して $1.0 \mathrm{~mol} \%$ 担持した $\mathrm{K} / \alpha-\mathrm{Fe}_{2} \mathrm{O}_{3}$ 触 媒を用いて $30 \mathrm{wt} \%$ グリセリン水溶液を反応させた場合 の生成物収率を Fig. 5 に示す。

$\mathrm{K}$ を担持していない酸化鉄のみの触媒 $\left(\alpha-\mathrm{Fe}_{2} \mathrm{O}_{3}\right.$ 触媒 $)$ を用いた場合は，反応経路 I と反応経路 II の収率がそれ ぞれ約 15 と約 $40 \mathrm{C}-\mathrm{mol} \%$ であった。これに対し，Kを 担持した場合 ( $\mathrm{K} / \boldsymbol{\alpha}-\mathrm{Fe}_{2} \mathrm{O}_{3}$ 触媒) は, 経路 I の収率は約 $24 \mathrm{C}-\mathrm{mol} \%$ （主にアリルアルコール）と大幅に向上し, 経路 IIに含まれる成分の収率は約 $10 \mathrm{C}-\mathrm{mol} \%$ （カルボ ン酸, ケトン, アルデヒド）まで減少することを見出し た ${ }^{26)}$ 。経路II 触媒酸点上でのグリセリンの脱水によ り進行する反応である。酸化鉄にカリウムを担持するこ とで経路IIの反応が抑制されたことから，カリウムは触 媒の固体酸性質を弱めグリセリンの脱水反応を抑制する ことが可能であると考えられる。 $\mathrm{K}$ を担持することで, 酸化鉄触媒の固体酸性が消失することは，アンモニア昇 温脱離法（ $\mathrm{NH}_{3}-\mathrm{TPD}$ 法）とピリジン吸着 IR の測定から 確認した ${ }^{26)}$ 。

上記の,アルカリ金属担持による金属酸化物の固体酸 性質の抑制は，他の金属酸化物においても同様に観察さ れ, 経路IIに由来する脱水反応（アセトールやアクロレ インの生成）は抑制される。一方，グリセリンからアリ

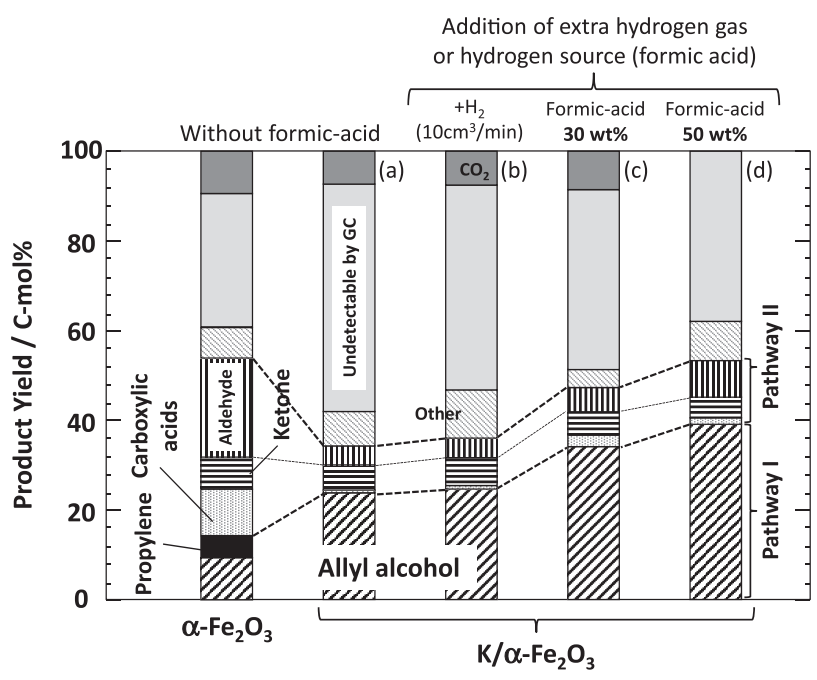

Fig. 5 Effects of potasium-loading on catalyst, and textra addition of hydrogen/hydrogen souraces to reaction system on the product yield.
ルアルコールが生成する反応経路 I は酸化鉄系触媒に特 徵的な反応であり，他の金属酸化物触媒ではほぼ観察さ れない。さらに, 経路 I のアリルアルコール生成は, $\mathrm{K}$ の担持により抑制されないため, 触媒の固体酸性質に由 来する単純な脱水反応とは異なると考えられた。また, グリセリンからのアリルアルコール生成反応においても 水酸基の脱離が進行しているため, 同反応を進行させる ための触媒の活性点の存在が不可欠である。そこで，グ リセリン転換反応前後における $\mathrm{K} / \alpha-\mathrm{Fe}_{2} \mathrm{O}_{3}$ 触媒の結晶 性と固体酸量と酸性質を測定し, 反応前と比較した。そ の結果，酸化鉄の結晶性はへマタイト構造 $\left(\boldsymbol{\alpha}-\mathrm{Fe}_{2} \mathrm{O}_{3}\right)$ からマグネタイト構造 $\left(\mathrm{Fe}_{3} \mathrm{O}_{4}\right)$ へ変化していることが 明らかとなった（Fig. 6 参照，図中の 5 (a) -5 (d) は Fig. 5 の実験条件に該当)。さらに, 触媒への $\mathrm{K}$ の担持 によりはほぼ消失していた固体酸性質が, 反応後の触媒 からは観察され, 酸性質がルイス酸からブレンステッド 酸（変性後の $\mathrm{Fe}_{3} \mathrm{O}_{4}$ 表面に新たに形成）へと変化してい ることが明らかとなった。反応中に触媒の結晶性がへマ タイト構造からマグネタイト構造へと変化し，マグネタ イト上に形成されるブレンステッド酸点がグリセリンか らのアリルアルコール合成に有効であることが示唆され た。

反応中における触媒の結晶構造の変化（へマタイトか らマグネタイトへの変性）と固体酸性の発現（ブレンス テッド酸点の発現)が, グリセリンからのアリルアルコー ル生成に影響することが示唆された。もう一つの検討事 項として, 酸化鉄のへマタイトからマグネタイトへの還

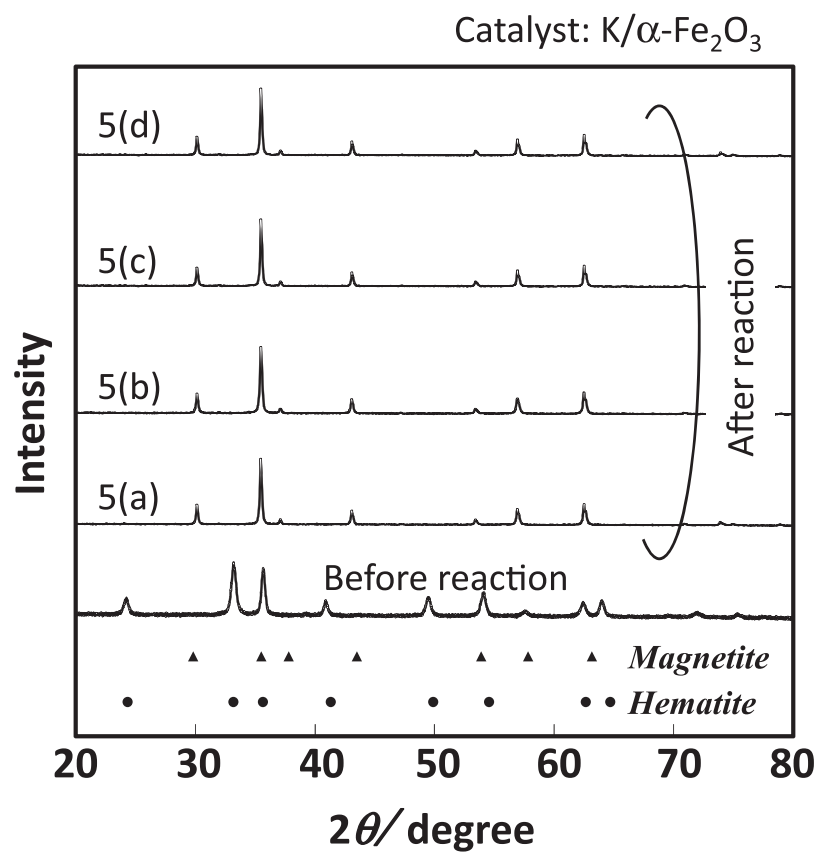

Fig. 6 X-ray diffraction patterns of catalysts before and after glycerol ocnversion. 
元とグリセリンの水酸基の除去に必要な水素種は何処か ら来るのか? が挙げられる。反応系には, キャリアガス の窒素と反応原料のグリセリン水溶液を供給しているの みであり，水素等は供給していない。にもかかわらず, 酸化鉄はマグネタイト型へ還元され，水酸基は除去され ると共に, 出口ガスからは水素が検出された。へマタイ トからマグネタイトへの変性が進行する還元的な反応雲 囲気が形成される一因として，反応中間体や副生物から の水素種の生成が考えられる。グリセリンからの転換反 応では, 中間体であるアセトールの分解, およびアクロ レイン生成時にギ酸が副生することが知られている。ギ 酸は金属原子上に吸着してギ酸イオン（formate）を形 成し, 容易に脱水素や脱水反応が進行するため, 反応中 間生成物としては検出されていない。しかし，上述した ように，ギ酸を添加しないグリセリン水溶液のみを反応 させた場合においても水素の生成が観察されたことか ら，反応中間体としてギ酸が副生すると共に，反応に関 与することが示唆された。アリルアルコール生成に作用 するギ酸由来の水素の形態として，分子状水素か原子状 水素であるのかを判断するため，水素源による生成物へ の影響を検討した（Fig. 5）。原料の $30 \mathrm{wt} \%$ グリセリン 水溶液とともに, 水素源として, $10 \mathrm{~mL} / \mathrm{min}$ 水素ガス, またはギ酸水溶液（30 wt％，50 wt\%）を添加し反応を 行った (Fig. 5 参照)。触媒には K 担持酸化鉄触媒 (K/ $\alpha-\mathrm{Fe}_{2} \mathrm{O}_{3}$ 触媒）を用いた。水素ガスを添加した場合のア リルアルコール収率は $25 \mathrm{C}-\mathrm{mol} \%$ であり，グリセリン のみを反応させた場合の収率 $24 \mathrm{~mol} \%$-Carbon と大き な違いが見られなかった。 $30 \mathrm{wt} \%, 50 \mathrm{wt} \%$ のギ酸水溶 液を併給した場合，アリルアルコール収率はそれぞれ約 $34 \mathrm{C}-\mathrm{mol} \%$ ， 約 $40 \mathrm{C}-\mathrm{mol} \%$ となり大幅に増加した。以上 の結果より，酸化鉄系触媒によるグリセリンからのアリ ルアルコール生成では, マグネタイト構造への結晶性の 変化, ブレンステッド酸点の発現, ギ酸由来の水素種が 関与することが明らかとなった。また，同触媒反応系で は，原料として粗製グリセリと試薬グリセリン水溶液を 使用した場合において，ほぼ同様の生成物が得られるこ とから, 酸化鉄系触媒は, アルカリ金属, 遊離脂肪酸等 に対しても高い耐性を有することが明らかとなった。

\section{4 おわりに}

バイオマス資源は, 油脂や草本系に加えて, 廃棄物系 バイオマス等，多岐にわたる。一方，バイオマス資源の 構成元素は炭素, 酸素と水素であり，構成比が異なるも のの化石資源と構成元素はほぼ同じである。ただし，分 子内に含まれる酸素が多いため（酸素／炭素モル比う 1)，酸素の除去が必須となる。バイオマスに含まれる物
質の分子構造は, 直鎖状の炭化水素, 芳香族, もしくは 5 員環, 6 員環等の特徵があり, 基礎化学物質の原料と して有望である。バイオマス由来の特徵的な分子構造を 維持しつつ, 化学転換が可能になれば, これまでとは異 なる全く新しい展開が拓けると考えている。

\section{謝辞}

本研究の一部は, 科学研究費補助金, 日本石畧洗剂工 業会, および先端的低炭素化技術開発（ALCA）の助成 により行われました。ここに記して謝意を表します。

\section{文 献}

1）一般財団法人 油脂工業会館, 平成 15 年度報告書 世 界の油脂原料事情.

2) T. Tago, Y. Nakasaka, T. Masuda, J. Japan Petrol. Inst., 57, 197-207 (2014).

3) H. Fukuda, A. Kondo, H. Noda, J. Biosci. Bioeng., 92, 405-416 (2001).

4) A. Behr, J. Eilting, K. Irawadi, J. Leschinski, F. Lindner, Green Chem., 10, 13-30 (2008).

5) D. G. Lahr, B. H. Shanks, J. Catal., 232, 386-394 (2005).

6) T. Miyazawa, S. Koso, K. Kunimori, K. Tomishige, Appl. Catal. A-Gen., 329, 30-35 (2007).

7) T. Kurosaka, H. Maruyama, I. Naribayashi, Y. Sasaki, Catal. Commun., 9, 1360-1363 (2008)

8) Y. Nakagawa, K. Tomishige, Catal. Sci. Technol., 2, 179-190 (2011).

9) Y. Nakagawa, M. Tamura, K. Tomishige, ACS Catal., 3 , 2655-2668 (2013)

10) T. Miyazawa, Y. Kusunoki, K. Kunimori, K. Tomishige, J. Catal., 240, 213-221 (2006).

11) S. H. Chai, H. P. Wang, Y. Liang, B. Q. Xu, J. Catal., 250, 342-349 (2007).

12) E. Tsukuda, S. Sato, R, Takahashi, T. Sodesawa, Catal. Commun., 8, 1349-1353 (2007).

13) A. Corma, G. W. Huber, L. Sauvanaud, P. O'Connor, J. Catal., 257, 163-171 (2008).

14) S. Sato, M. Akiyama, R. Takahashi, T. Hara, K. Inui, M. Yokota, Appl. Catal. A-Gen., 347, 186-191 (2008).

15) R. A. Sheldon, Green Chem., 16, 950-963 (2014).

16) T. Masuda, Y. Kondo, M. Miwa, T. Shimotori, S.R. Mukai, K. Hashimoto, M. Takano, S. Kawasaki, S. Yoshida, Chem. Eng. Sci., 56, 897-904 (2001).

17) H. Kondoh, N. Hasegawa, T. Yoshikawa, Y. Nakasaka, T. Tago, T. Masuda, Energy \& Fuels, 30, 10358-10364 (2016).

18) H. Kondoh, Y. Nakasaka, T. Kitaguchi, T. Yoshikawa, T. Tago, Takao Masuda, Fuel Proc. Technol., 145, 96-101 (2016).

19) D. Na-Ranong, R. Yuangsawad, T. Tago, T. Masuda, Korean J. Chem. Eng., 25, 426-430 (2008).

20) D. Mansur, T. Yoshikawa, K. Norinaga, J. Hayashi, T. Tago, T. Masuda, Fuel, 103, 130-134 (2013).

21) S. Funai, Y. Satoh, Y. Satoh, K. Tajima, T. Tago, T. 
Masuda, Top. Catal., 53, 654-658 (2010).

22) T. Yoshikawa, T. Yagi, S. Shinohara, T. Fukunaga, Y. Nakasaka, T. Tago, T. Masuda, Fuel Proc. Technol., 108, 69-75 (2013).

23) D. Mansur, M. Shimokawa, K. Oba, Y. Nakasaka, T. Tago, T. Masuda, Fuel Proc. Technol., 108, 139-145 (2013).
24) T. Yoshikawa, T. Tago, A. Nakamura, A. Konaka, M. Mukaida, T. Masuda, Res. Chem. Intermed., 37, 12471256 (2011).

25) A. Konaka, T. Tago, T. Yoshikawa, Y. Nakasaka, T. Masuda, Ind. Eng. Chem. Res., 52, 15509-15515(2013).

26) A. Konaka, T. Tago, T. Yoshikawa, Y. Nakasaka, T. Masuda, Appl. Cbem. B., 146, 267-273 (2014). 